\title{
The New Components of Catalan Nationalism
}

\author{
Erika Jaráiz, Ángel Cazorla, José Manuel Rivera \\ University of Santiago de Compostela, Santiago de Compostela, Galicia, Spain \\ Email: erika.jaraiz@usc.es
}

How to cite this paper: Jaráiz, E., Cazorla, Á., \& Rivera, J. M. (2019). The New Components of Catalan Nationalism. Open Journal of Political Science, 9, 163-188. https://doi.org/10.4236/ojps.2019.91009

Received: November 30, 2018

Accepted: January 15, 2019

Published: January 18, 2019

Copyright (c) 2019 by author(s) and Scientific Research Publishing Inc. This work is licensed under the Creative Commons Attribution International License (CC BY 4.0).

http://creativecommons.org/licenses/by/4.0/

\begin{abstract}
In this paper we identify four fundamental factors in the construction of the nation-preconditions, political opportunity structure, mobilization and speech-, integrated by a series of elements that serve as indicators for the approach to our explanatory model. With our analysis we demonstrate that in Catalonia nationalism is explained by contextual elements, elements of mobilisation, fundamentally the leadership, and by the "process" itself. These findings allow us to talk about a Catalan nationalism constructed on the bases of reasons that have to do with unjust treatment by Spanish governments, trust and expectations.
\end{abstract}

\section{Keywords}

Nationalism, Catalonia, Process, Identity

\section{Introduction}

Over the last few years we have witnessed the development of a pro-independence movement ${ }^{1}$ in Catalonia hand in hand with the growth of the nationalist parties, the gradual homogenisation of the objectives of these parties and the escalation of tension between the governments of Catalonia and Spain. During this time, hardly anything in Spanish or Catalan politics has been immune to that independentist tension or to that nationalist upturn, which has resulted in electoral coalitions that transcend the left-right "cleavage" and have necessitated the repositioning of all the terms with regard to a new hegemonic "master frame": the process (the secession process).

With this framework as a reference, the entry of new parties into Catalan political competition, as it is the case in Spain, has left a political panorama, following the autonomous elections of 2015, marked by complexity, fragmentation

${ }^{1}$ The Catalan pro-independence movement socially articulates from citizen mobilization through historical cultural associations like Òmnium Cultural (1961) or Assemblea Nacional Catalana (ANC) that arose from the Conferència Nacional per l'Estat Propi in 2011. 
and instability. The difficulty to form government, after the forced abandonment of ex-president Mas, was succeeded by a period of governmental instability anchored to the weakness of the links between the government and its parliamentary partners, and the classic tension between pragmatism and ideology that Sartori, Ware, Przeworsky and Stone, amongst others, point to in political parties; but also by the very instability of the decision-making model, especially of the anti-system party CUP, which means that nothing guarantees the coherence of a decision with the one taken previously.

In this article we seek to renew questions and methodologies so as to be able to analyse, via a dynamic, evolutionist and constructivist reading the national question in Catalonia. We will attempt to explain the degree to which the growth of identity-based nationalist feeling, and the incorporation of new elements and actors into political competition, were related to the development of attitudes towards secession, and if this was the case, discover which factors influenced the genesis of that identity and those attitudes. And all that with our own data, the result of a specially-designed opinion poll to address the different aspects of the nationalist conflict (Post-electoral Study Autonomous Elections in Catalonia $2015)^{2}$.

\section{The Theoretical Approach to Nationalisms}

The classic argument in the explanation of the emergence of nationalism has traditionally adopted a pre-political and primordialist conception of the nation. In this perspective, nation pre-exists nationalism, and the differential ethnic-cultural preconditions, such as language, history, culture or religion, diacritical correlates of identity, are the starting point for the appearance and generalisation of national identity. The existence of those objective differences, preconditions of the national conscience, catalyse the formation of a series of common interests which, in turn, will generate shared values, giving rise to the emergence of a national identity that will materialise politically, sooner or later, in a movement, nationalism. In this way, the objective preconditions of the nation are the basis for the formation of identity and upon this is generated, as its necessary reflection, the movement, political action, and the actors who express or externalise the national identity pre-established in history.

The traditional approaches to nationalisms, be it via a historical vision based on maxims like "the nation exists in time" (Kumar, 2006: p. 12) or the nation "taken as given" (Kymlicka, 2001), be it of a cultural or a structural nature, have in turn constructed an interpretation of this formulation of the nation as a pre-

\footnotetext{
${ }^{2}$ Performed by our own research team in the days following the Catalan elections, between November $16^{\text {th }}$ and December $23^{\text {rd }}$ of 2015 , this is a study structured into eleven thematic blocks analysing the population over eighteen years of age resident in Catalonia. The theoretical simple size of the study is 1400 interviews, under the most unfavourable assumption $p=q$, with an associated error of $\pm 2.62 \%$ and with proportional allocation by quotas of gender, age and province. The questionnaire was conducted by telephone via CATI (Computer-Assisted Telephone Interviewing) system. This study was financed in the frame of the "Ayudas para la consolidación de unidades de investigación de la Xunta de Galicia, GPC2015/011".
} 
political phenomenon, which transforms nationalism into a mere, albeit legitimate and unique, expression or representation of a given nation, socially crystallised. Meanwhile, the interpretations of "national culture" as a culture created via the "invention of tradition" (Hobsbawm, 1998; Hobsbawm \& Ranger, 1983), or of the nation as "imagined community" (Anderson, 1983), has served more to emphasise the idea of creation, of cultural and mythical-symbolic construction, than the actual political constitutive dimension of the nation. On the basis of these culturalist readings, myth, nation, is built, is imagined, is even "invented", it is a cultural construction which sinks its routes into the past, which is interpreted and developed via a linear progression, and which pre-exists political construction and in that sense continues to be exogenous to political confrontation itself. Thus, the idea of pre-existing nation generates an undisputed frame for political argumentation and for electoral competition, in which the nationalist parties are perfectly situated, but in relation to which non-nationalist parties and voters must also position themselves.

The problem presented today by the pre-political conception of the nation is its allergy to evolution, its linearity, its static character, based on the socio-structural nature of the preconditions of identity and in the absence of dynamism of the culture itself, guided fundamentally by ethnicity, the result of its expressive and politically exogenous nature. However, from our perspective, what the Catalan process has shown, is that national identity is dynamic, evolves, incorporates new actors, new arguments which alter the bases and the linearity of its own construction, which questions the preconditions of identity, and even, the need for immutable ethnic-cultural elements upon which to establish itself or develop. For this reason, interpretation and analysis of this dynamism, affected by factors strategically linked to political competition, require to abandon static and pre-political conceptions of the nation to understand nationalism as a decisive factor in the very production of nations. To give an account of its enormous capacity to mobilise, addressing both the factors through which it is affirmed, such as the generalisation and reaffirmation of the existence of a catalan nation constructed as "internally homogeneous" and clearly differentiated from "others", in which national identity plays a decisive role, assuming that "nationalism is not engendered by nations. It is produced -or better, it is induced-by political fields of particular kinds" (Brubaker, 1996: p. 17). Even analyses that subscribe to alogic of demand, in other words, the emergence of nationalist parties as a political response to a pre-existing national identity, need to admit a certain logic of offer. Indeed, that national identity has been the product, in turn, of the prior political mobilisation of nationalist leaders, movements and parties (Boonen \& Hooghe, 2014: p. 72). Therefore, in our perspective, it is not that Catalan national identity does not constitute a fundamental dimension of the individual identity of the citizens of Catalonia, transmitted intergenerationally (Rico \& Jennings, 2012). Our point is rather that this shared identity is subject to highly diverse political articulations and possibilities, both in what affects the nature of the contrast us/them, self/other etc. ... and the political demands for self-government 
defended in given circumstances. Nothing of all this is inscribed in a "natural" way in the identity-based substratum of the Catalan nation, but is the result of a complex, conflictive and contingent process of political construction.

It is the nationalist discourse, and its organisational articulation, which (re)constructs the specific idea of nation, which hews the identity shared by citizens, which establishes the "will to be" nation and produces it by means of political action. Thus, the explanations of policies related to ethnicity, as a constitutive element of the nation, appear at the centre of the field of strategies (Hale, 2008), and specifically in that of political/electoral strategy. Nationalist discourse, articulated in this manner, is an effective combination of essentialist and strategic elements, of interests and emotional ties, which are sufficiently virtual and flexible to include at one given moment essentialist elements of the nation, and at another radically strategic elements, to the point of altering the character of elections to the autonomous Parliament of Catalonia (2015) so as to transform them into a national plebiscite, turning the very question of independence into an "issue" of political competition. It is that open-ended flexibility, which facilitates the coordination of the nationalist movement and feeds back the interpretative frame in which the idea of nation is constructed as "a product of cultural coordination and the claim of statehood or political autonomy for the population that successfully coordinates" (Laitin, 2007: p. 41). A process more complex still in societies with different national identities, where people decide who they wish to share a country with, asking themselves with whom do they identify and towards whom do they profess a sentiment of empathy and solidarity, or rather of mistreatment and resentment.

The necessary relationship between culture and political coordination does not require, however, the homogeneity of the community, even in terms of its political values. Certainly, the assumption of a shared culture does not mean that all its members assume the same values, and therefore, cultural homogeneity is not an indispensable prerequisite. Thus, it is possible to understand shared readings from different ideological positions, as has occurred in the Catalan case, and even the movements of citizens and parties within ideological spaces.

Catalan nationalism, like all nationalisms, interacts, evolves ideologically, in very diverse ways, influenced by competition and external and internal tensions (Shelef, 2010). Moreover, in plurinational States the political demands of internal nations are the contingent result of not only 1 ) the identity-based construction of nations and 2) the economic, political and cultural interests of the different communities, but also 3) the interactive process between institutional arrangements (territorial state model), 4) the policies (fiscal, competence-related, linguistic etc.) of central government, and 5) the discursive strategies and framing of the leaders and parties in competition (Hale, 2008). Nationalism politically re-signifies and (re)constructs the nation, established upon two elements that assume the character of precondition (ethnic-cultural preconditions and economic-social preconditions), and two others of a strategic-organisational na- 
ture-a structure of political opportunity and efficient political mobilisation (Máiz, 2003a), and articulated (Máiz, 2003b) by means of a discourse that creates the frame in which these elements acquire political and competitive value.

So, the nation does not pre-exist national construction, because the historical and ethno-cultural differences are insufficient. Though the demand, which emerges from a previous identity, plays an undeniable part (Boonen \& Hooghe, 2014), what is most important in explanatory terms is the offer, in other words, the political work upon that demand via an articulating discourse and a successful nationalist mobilisation and leadership for the generation of a nation. It is not the nation which generates nationalism as its necessary manifestation and externalisation, but nationalism which, in certain contexts and in competition with other forces and ideologies, configures the nation in a permanently open and endless political process. A process in which what is at stake is not only the success or failure of national construction (in other words, the nation as a phenomenon of masses and not only elites), but political orientation (inclusive or xenophobic) and national demands (federalism or secession). Only politics, via its discursive, strategic construction of leadership, organisational and institutional, can cannel the dynamism of this construction.

Over the following pages we will try to explain how these elements function in the Catalan case and the weight they have had in the construction of Catalan national identity, on the basis of the confirmation of the increase in nationalist sentiment among citizens, and the steady drift of the latter towards increasing secessionist positions. The relationship between these two elements, nationalism and independentism, is not, however, something self-evident or "natural", but one strategic option, amongst others, whose origin, extension and scope must be explained. Neither does "independence" constitute a unique political objective, or a demand devoid of ambiguity. On the contrary, it is a polysemic term under which compete many different projects and demands for self-government, as is demonstrated by comparative politics, from Scotland to the Ukraine, passing through Uzbekistan or Quebec ("Independence-Lite", "Semi-sovereignty", "Partial Independence”) (Keating, 2009; Keating, 2012; Hale, 2008; Rezvani, 2014). The traditional discourse of nationalism stems from a performative tenet: the objective pre-existence of conditions generating national identity, and that this national identity leads, ultimately and irrevocably, to the quest for independence. In this sense, for traditional nationalism, secession possesses an implausible immanent and teleological sense, like an a priori tenet, with political action being only the natural and necessary means to achieve, sooner or later, that unavoidable end.

Our constructivist reading requires this new perspective insofar as it acknowledges that the placement of citizens on the nationalist scale, for instance, is a politically produced position, which responds to an endogenous construction of the preferences that lead some citizens to situate themselves at one point and others at another. From this perspective we identify the utility of the analytical scheme (Figure 1) proposed by Máiz (2003a, 2003b, 2012) for the constructivist 
explanation of the nation which incorporates four fundamental factors in each in constant interaction with the others: 1) The existence of differentiated social preconditions (ethnic-cultural, economic, ...); 2) the presence of a favourable political opportunity structure (national and international institutional context, actors, electoral competition ...); 3) efficient nationalist mobilisation (organisation, leadership, repertoire of mobilisation); and 4) a plausible nationalist discourse with a capacity for constitutive national interpellation (identity-based strategies, demands for self-determination).

None of these factors is exogenous to political construction itself, even social preconditions are elaborated as such sometimes via the definition of the nationalist discourse, sometimes via the production of the economic and political prospects of Catalonia in Spain and the European Union. Neither is the structure of opportunity simply the fruit of an "objective" context, quite to the contrary, both the institutional context and realignments and competition between actors are created according to the discourse that sustains each of the elements that make up the diagram. Opportunities are always "perceived opportunities" by the actors and, furthermore, each successful mobilisation opens, increases earlier opportunities (making opportunities). Political mobilisation incorporates individual and collective actors into national construction, because unlike the logic of traditional collective action, expressive of a previously established nation, this realist-constructivist reading help us to understand the temporalisation of the endogenous of nationalist preferences and with it the consistency of the individualised or collective production of "national interests" or demands of self-government as appropriate.

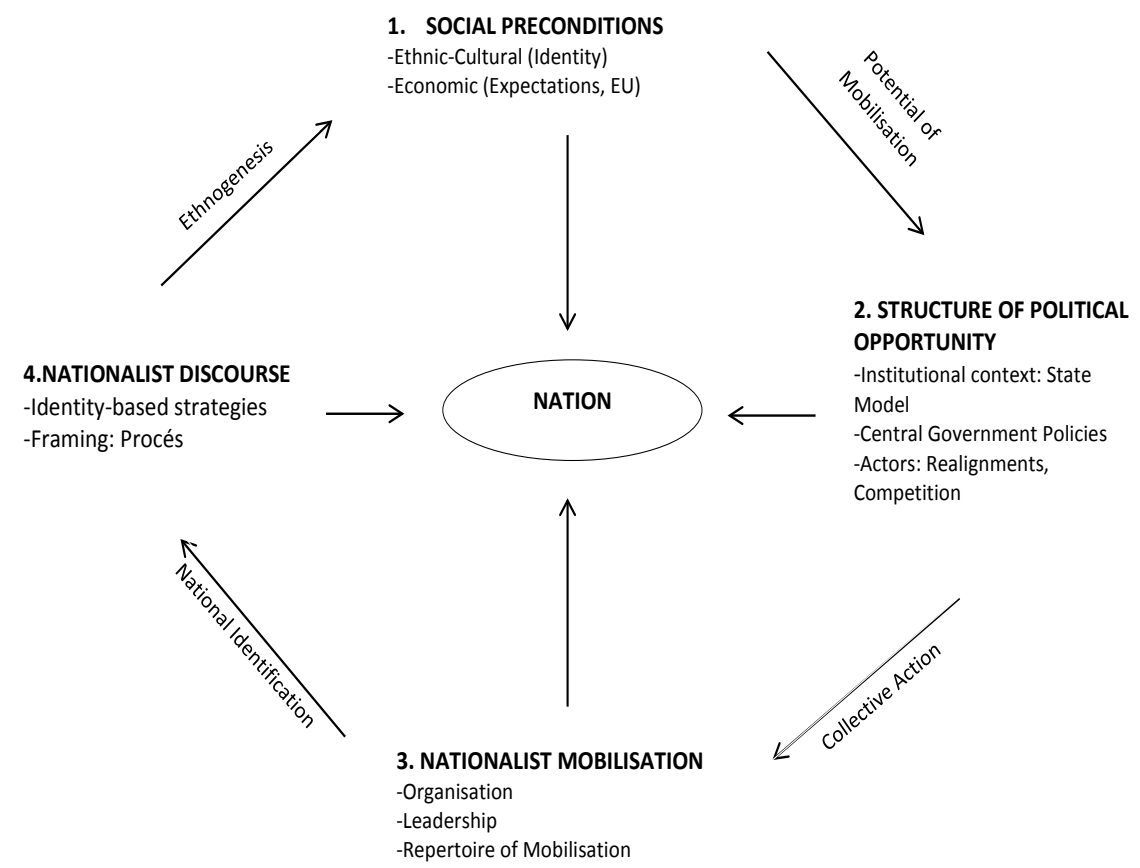

Figure 1. Nation and nationalism. Relational constructivist model (factors). Source: adapted from Máiz, 2012. 
In this sense, opportunity, mobilisation and discourse interact as aspects of competition, coexist temporally and strategically and, via realignments, leaderships and the "process" itself, become strategically fundamental elements of the electoral competition. Thus, analytical diagram proposed by Máiz that we employ in this study, beyond its explanatory vocation of nations as political phenomena (not merely ethnic, or social), permits an interpretation of the electoral competition as an exogenous expression but as a key political moment in the production of the nation and, in our case, a study of the incidence of the competition itself in the construction of Catalan national identity.

\section{Factors of the Competition That Influence the Production of the Catalan Nation}

\subsection{Social Preconditions}

Unlike the traditional idea of objective and exogenous social preconditions, linked to the diacritic elements of identity-language, ethnicity, culture, religion-that have generated essentialist nationalism, the new Catalan nationalism de-ethnifies and politicises the nation; in other words, is generated in connection with new conditions-the economic crisis-and expectations-confidence in a future as an independent State within the EU-which sustain the substrata upon which the process is developed.

Historically, Catalan nationalism has been characterised by its high degree of fragmentation, by its propensity for strategic alliance, conditional upon the presence of external elements that might threaten common ground, as well as by the constant mutation of its drive shafts, be they cultural, historical, economic or political. $\mathrm{CEO}^{3}$ data shows that since 2010 unemployment and job insecurity-the economic crisis-have become the main concerns for the Catalans, shooting up to percentages in excess of 80 per cent from 2008 onwards, whilst concern about relations between Catalonia and Spain-affected by a crisis of confidence-has grown among Catalans throughout the period of crisis, becoming number one concern in Nov $2018^{4}$. Similarly, dissatisfaction with politics appeared as another constant theme during the period 2008-2018.

This perception of economy and politics in Catalonia is related to nationalist attitudes, and to understand it one needs only to see the gradation that exists with regard to the evaluation of politics and the economy in this Community depending on the position of citizens on the nationalist scale. Table 1 shows the relation between the evaluation of Catalan politics and economy, and its evolution, and the average self-placement of Catalans on the nationalist scale. The more positive and optimistic visions of the Catalan economy correspond to those with a clearly more nationalist self-positioning whilst, on the other hand, as one descends the scale these evaluations, both economic and political, are much more negative.

${ }^{3}$ Centre de Estudis de Opinió, demoscopic body affiliated to the Generalitat de Catalunya. ${ }^{4}$ CEO Data, Barometer of November 2018. Product of the sum of the first and second problem manifested by the Catalans. 
Table 1. Average self-placement on the nationalist scale according to contextual perceptions.

\begin{tabular}{|c|c|c|c|}
\hline \multicolumn{4}{|c|}{ Average self-placement on the nationalist scale } \\
\hline & & Average & Standard Deviation \\
\hline \multirow{7}{*}{ Catalan economy } & Very good & 8.23 & 1.75 \\
\hline & Good & 6.45 & 3.09 \\
\hline & Normal & 5.71 & 3.24 \\
\hline & $\mathrm{Bad}$ & 5.61 & 3.40 \\
\hline & Very bad & 4.54 & 3.80 \\
\hline & DK & 4.13 & 4.86 \\
\hline & NA & 5.23 & 0.85 \\
\hline \multirow{7}{*}{ Catalan politics } & Very good & 9.26 & 1.15 \\
\hline & Good & 8.01 & 2.20 \\
\hline & Normal & 6.62 & 2.92 \\
\hline & Bad & 5.60 & 3.17 \\
\hline & Very bad & 3.96 & 3.42 \\
\hline & DK & 8.08 & 580 \\
\hline & NA & 8.46 & 1.57 \\
\hline \multirow{4}{*}{ Evolution economy } & Will improve & 7.32 & 2.77 \\
\hline & Will remain the same & 6.17 & 3.07 \\
\hline & Will get worse & 3.28 & 3.11 \\
\hline & $\mathrm{DK} / \mathrm{NA}$ & 6.30 & 3.01 \\
\hline \multirow{4}{*}{ Evolution politics } & Will improve & 7.28 & 2.83 \\
\hline & Will remain the same & 5.67 & 3.27 \\
\hline & Will get worse & 3.46 & 3.13 \\
\hline & DK/NA & 6.32 & 2.77 \\
\hline
\end{tabular}

Source: Own data from the Post-electoral Study Autonomous Elections in Catalonia 2015.

The fact is that, in a way, Catalan nationalism has demonstrated its ability to unite and reorder not only political spaces, as we have seen in previous chapters, but also the economic and political concerns of the Catalans; all of this at the same time as the increasing evolution of the nationalist positions of citizens (Figure 2) in favour of an independent State (the latter have trebled in recent years, from a percentage of around 15 per cent in the period prior to the crisis, to representing approximately half of the citizens). Prat (2012), has indicated four moments when this evolution of nationalist and secessionist sentiments has occurred: 1) a period of certain stability between 2005 and April 2009, when support stood at about 15 per cent; 2) sustained growth between April 2009 and June 2011, when it reached 25 per cent; 3) a genuine acceleration after that, when it rose from 29 per cent (June 2011) to 34 per cent (June 2012), with an in- 
crease of 5 per cent in just a year; and 4) consolidation of these positions and the division of citizens into two practically symmetrical groups (in June 216 support for independence reached 47 per cent).

Table 2 shows us how the shift of identity-based sentiment has been produced from evenly shared positions to exclusively nationalist positions, with the number of those who feel Catalan today doubling the number ten years ago. The evolution is observed mainly in the increase in the number that say they feel "only Catalans", passing from a 14.5 per cent in 2006 to a 26.3 per cent in 2016, and in the decline of those who feel "only Catalans", from a 44.3\% in 2006 to a $33.8 \%$ ten years later. In similar fashion, support for independence, traditionally minority within Catalan nationalism, has in recent years even exceeded the limits of what had heretofore been understood as nationalism (Figure 1). In this sense, confidence in the Catalan political classes and the expectation of better dealing with problems separate from Spain, have become the driving force behind a new idea of Catalan nation that has been built in recent years. And this construction has taken place beyond the symbolic, cultural and historical elements which traditionally defined it, finding a new articulation via the intermediary role of politicians and strategies that have been able to cannel sentiments and attitudes related to political distrust-linked to the rejection of State-oriented positions and actors-and trust in Catalan actors and institutions.

Meanwhile, more traditional diacritic elements, such as one's own language, have lost significance to the extent that only around 30 per cent of voters of the parties that support the process communicate exclusively in Catalan. In this respect, language has ceased to be an element of confrontation because there are new elements, of a strategic nature, which have acquired more weight than components of a traditional cultural nature and which result in the new nationalism having a reduced essentialist component (History, Language, Myths etc.) and, instead, a very solid and creative political content.

Table 2. Evolution of nationalist sentiment (2006-2016).

\begin{tabular}{|c|c|c|c|c|c|c|}
\hline \multirow[b]{2}{*}{ Year } & \multirow[b]{2}{*}{ Catalan only } & \multirow{2}{*}{$\begin{array}{c}\text { More } \\
\text { Catalan than } \\
\text { Spanish }\end{array}$} & \multirow{2}{*}{$\begin{array}{c}\text { Equally } \\
\text { Catalan and } \\
\text { Spanish }\end{array}$} & \multicolumn{2}{|l|}{ More } & \multirow[b]{2}{*}{ DK/NA } \\
\hline & & & & $\begin{array}{c}\text { Spanish than } \\
\text { Catalan }\end{array}$ & Spanish only & \\
\hline 2006 & $14.5 \%$ & $27.2 \%$ & $44.3 \%$ & $4.7 \%$ & $6.1 \%$ & $1.2 \%$ \\
\hline 2010 & $20.3 \%$ & $25.5 \%$ & $42.5 \%$ & $3.9 \%$ & $5.5 \%$ & $2.3 \%$ \\
\hline 2011 & $20.5 \%$ & $29.5 \%$ & $39.3 \%$ & $3.3 \%$ & $5.0 \%$ & $2.4 \%$ \\
\hline 2012 & $22.7 \%$ & $30.2 \%$ & $37.3 \%$ & $3.5 \%$ & $4.0 \%$ & $2.3 \%$ \\
\hline 2013 & $23.4 \%$ & $27.2 \%$ & $38.2 \%$ & $2.6 \%$ & $3.7 \%$ & $4.7 \%$ \\
\hline 2014 & $24.6 \%$ & $26.0 \%$ & $38.2 \%$ & $3.5 \%$ & $4.2 \%$ & $3.4 \%$ \\
\hline 2015 & $27.6 \%$ & $24.6 \%$ & $35.2 \%$ & $3.1 \%$ & $5.7 \%$ & $3.7 \%$ \\
\hline 2016 & $26.3 \%$ & $24.2 \%$ & $33.8 \%$ & $5.7 \%$ & $5.1 \%$ & $5.0 \%$ \\
\hline
\end{tabular}

Source: Own data based on the barometers of the Centre d Estudis d Opinio. 


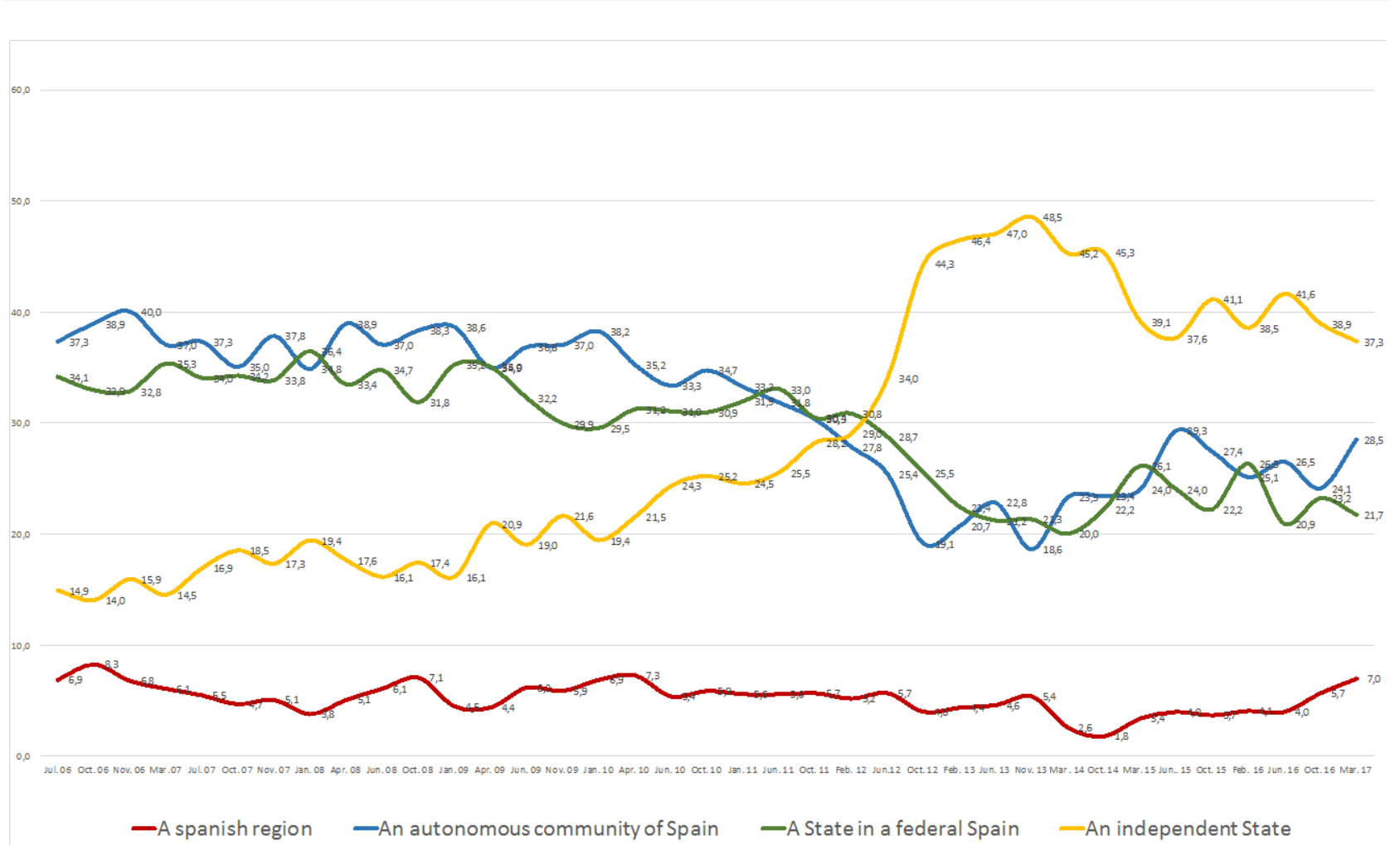

Figure 2. Evolution of preferences regarding the territorial organisation of Catalonia. Source: Own data from Centre $d$ Estudis d Opinió (Baròmetre d'Opinió Política 2010-2016).

\subsection{The Structure of Political Opportunity}

Rather than the idea that the structure of political opportunity is cumulative, in other words, arises owing to a favourable series of events generated from the institutional context, the Catalan phenomenon shows us that the structure of opportunity does not pre-exist mobilisation, but is read, interpreted and widened by the narrative that gives life to the latent elements of opportunity, which not only transfers but, in reality, reinforces their potential for mobilisation, which converts them into "issues" of competition, and it is the same actors present that generate these scenarios of competition by means of mobilisation.

The "process", constructed as "master frame" and strategically employed as "issue", becomes, in Catalonia, the key articulator of political competition, capable of redirecting identity-based positions of part of the Catalan population, even, as we have shown, beyond the latter's ideological and nationalist foundations. The problem now is to evaluate whether the elements by means of which this new nationalist space is incorporated are the same ones that constituted the foundations of traditional nationalism or, as is revealed to us by descriptive reading, they are also new. In order to do this we must begin by discovering if there is a new sociodemographic profile of nationalism and, if this is the case, what are the elements that explain this identity-based reading.

From an initial descriptive reading, we observe that the average self-placement of Catalans on the nationalist scale is high, specifically 6.23 on a scale of 0 to 10 , 
marking very polarised spaces, occupied in the zero position by 12 per cent who would declare themselves nationalist, whilst at the ten mark 18 per cent would place themselves at the nationalist maximum (Figure 3). Another interesting fact is that, if we ignore the 15 per cent who would place themselves in the middle position, those who locate themselves in a nationalist space (6 to 10 on the scale) represent 53.3 per cent of the population, compared to 19.7 per cent who would place themselves in non- or barely nationalist positions ( 0 to 4 on the scale).

Furthermore, it is interesting to highlight the enormous transversality of these positioning, insofar as the main sociodemographic characteristics of the population are not substantially different, most subgroups registering scores above or close to six on the scale (Table 3). It is true that one observes that people on a lower income (below $1000 €$ ) would be those scoring lowest on the scale, 4.33 average, and that there is an apparent relation between age and self-placementon the scale, so that, as age decreases, scoring rises. Something similar happens with regard to level of education, where slight differences are also apparent, especially in the case of those with a higher level of education, who present the highest scoring, although following ANOVAS for these sociodemographic variables, there is only confirmation of significant differences for level of education via robust statistics (in the absence of equality of variances). The only statistically significant differences refer to those between people with primary education and the remaining categories.

Table 3. Average self-placement on the nationalist scale according to sociodemographic.

\begin{tabular}{|c|c|c|c|}
\hline & & \multicolumn{2}{|c|}{ Nationalist self-placement } \\
\hline & & Average & Standard Deviation \\
\hline \multirow{2}{*}{ Sex } & Male & 6.18 & 3.27 \\
\hline & Female & 6.28 & 3.29 \\
\hline \multirow{4}{*}{ Age Groups } & 18 to 29 & 6.68 & 2.88 \\
\hline & 30 to 49 & 6.46 & 3.17 \\
\hline & 50 to 64 & 5.96 & 3.53 \\
\hline & 65 and over & 5.84 & 3.40 \\
\hline \multirow{8}{*}{ Level of Education } & No studies & 5.00 & 3.84 \\
\hline & Some years of primary education & 6.00 & 3.77 \\
\hline & Primary education & 5.31 & 3.41 \\
\hline & Secondary education & 6.08 & 3.31 \\
\hline & FP I and II & 6.10 & 3.12 \\
\hline & Estudios de grado medio & 6.94 & 3.08 \\
\hline & Estudios de grado superior & 6.63 & 3.19 \\
\hline & $\mathrm{DA}$ & . & . \\
\hline \multirow{3}{*}{ Ingresos } & Low & 4.33 & 3.46 \\
\hline & Medium & 5.88 & 3.31 \\
\hline & High & 6.63 & 3.08 \\
\hline
\end{tabular}

Source: Own data from the Post-electoral Study Autonomous Elections in Catalonia 2015. 


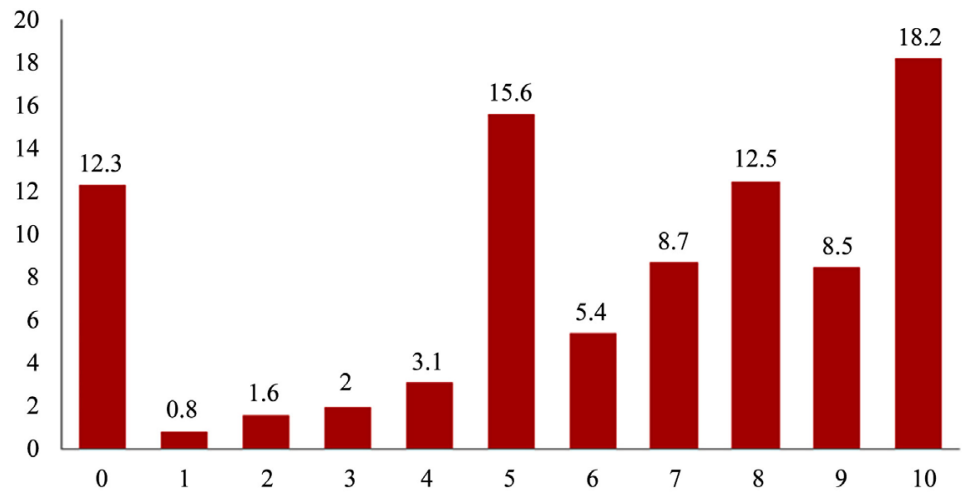

Figure 3. Self-placement on the nationalist scale (per cent) $)^{5}$. Source: Own data from Post-electoral Study Autonomous Elections in Catalonia 2015.

With regard to the influence of political factors on the opening of the structure of opportunity, one of the most interesting phenomena in the nationalist discursive construction, due to its impact on electoral alignments, is how national identity incorporates the "process", as if both things were just one; a kind of fusion of strategies and interpretative horizons which make it difficult to distinguish and almost impossible to analyse the relationships between both elements. Faithful to our approach, our research strove to deal with them in differentiated manner in order to individualise and analyse these relationships.

Figure 4 shows us the relationship between being in favour of or against the process and position on the nationalist scale. The first descriptive reading shows that while those who are in favour of the process clearly occupy high positions on the nationalist scale, those who are against do not do this in the same way in the low positions. While 85.8 per cent of those in favour of the process occupy positions 6 - 10, only 56.3 per cent of those who are against do so in positions 0 4 , and this is because 27.5 per cent of those who are against the process place themselves accommodative in the neutral position on the scale.

The increase in nationalism and homogenisation regarding secessionist demands transcend the actual ideological positioning of citizens and parties, generating a unified space towards which political parties from different ideological positions have been approaching, but also moving away. Thus, the traditional scheme of positioning framed by ideological and nationalist axes is superseded by the dynamic of the process, which becomes a catalyst of identity-based sentiments, generating decisive realignments of both parties and voters.

These realignments, which reveal the opening of the structure of opportunity at stake, will serve to show the weakness of nationalist homogeneity via analysis of three kinds of relationships: the first, the relationship between ideological self-placement and self-placement on the nationalist scale; the second between partisan identification (expressed via the question of sympathy) and ideological positioning; and the third, the relationship between partisan identification and nationalist positioning.

${ }^{5}$ The abscissa shows the different positions of the scale of nationalist sentiment, 0 to 10 , while the ordinate represents the percentage of Catalans placing themselves in each position. 


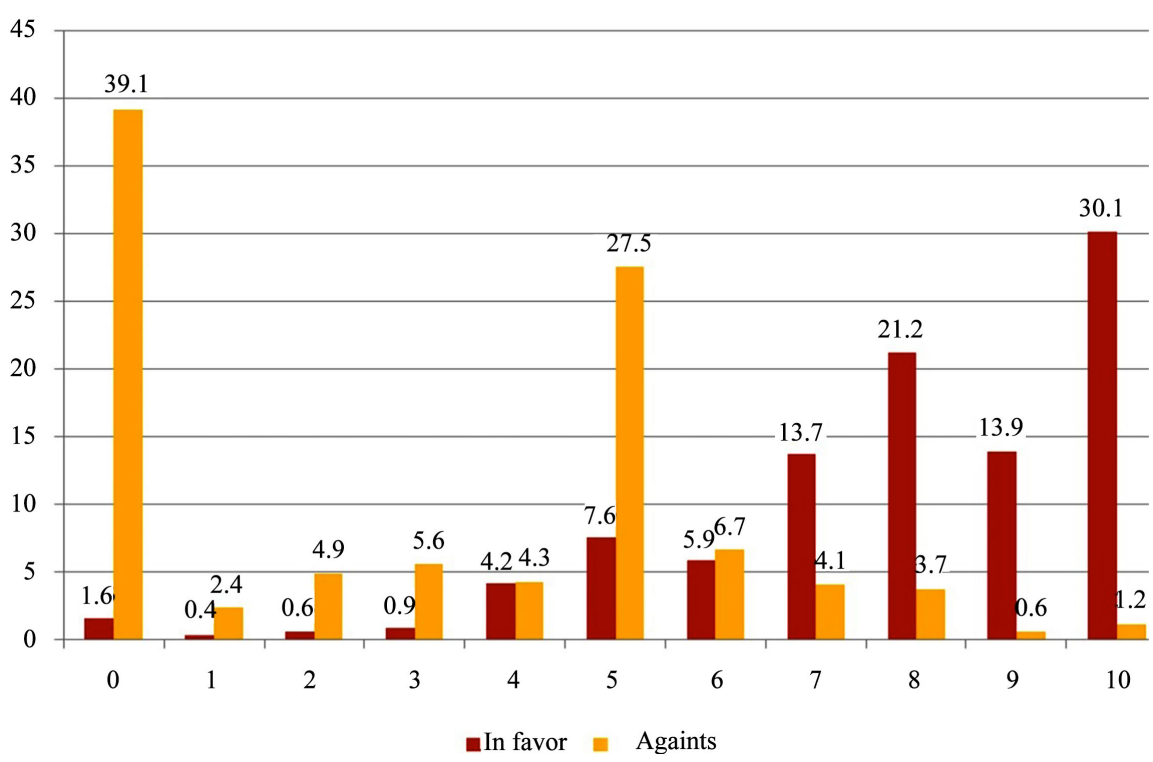

Figure 4. Self-placement on the nationalist scale and support for the independence process. ${ }^{6}$ Source: Own data from the Post-electoral Study Autonomous Elections in Catalonia 2015.

The first relationship was clearly demonstrated by Pereira (2016), and Rivera and Jaráiz (2016) recently, and shows the prevalence of the nationalist axis over the ideological one in its influence upon the vote. The other two relationships, however, have to be analysed taking into account the "sympathy" variable, which takes as references each of the parties which form the JxSí coalition, instead of the coalition itself. To this end we have performed a correspondence analysis of ideological self-placement with regard to sympathy and of the latter with self-placement on the identity-based scale. In this respect one can observe coincidental spaces between some parties, which is the case of PSC, C's and CatSíQueEsPot; although there are certain differences resulting fundamentally from CiU's position in both spaces and which clearly show how the process has structured political competition, attributing in the latter fundamental weight to the identity-based axis and relegating in particular CiU's ideological position. The latter is supported amongst other questions with the scant level of ideological coincidences which the analysis of calculation of ideological distances according to spatial models of vote showed in the case of the political coalition Junts pel Sí, compared with the high level of coincidences presented by the same formation when the distances analysed were identity-based.

Indeed, analysis of the correspondences between spaces of ideology with sympathy, as well as nationalism with sympathy enables us to show in graphic terms what we are commenting upon. The first of these cases (Figure 5), reveals the enormous correspondence between political parties and ideological spaces, in such a way that the Catalan electoral space reveals three clearly demarcated

${ }^{6}$ The abscissa shows the different positions of the scale of nationalist sentiment, 0 to 10 , while the ordinate represents the percentage of Catalans placing themselves in each position of the scale, depending on being in favour or against the process. 
ideological blocks: to the left (0 to 4 on the scale of ideological self-placement) there is perfect gradation between the most extreme values and support, in order, for CUP, IU, ERC, Podemos and the PSOE. Towards the centre and centre right (from 5 to 7 on the scale) we find CiU, CDC, UDC and Ciudadanos. Finally, on the far right (8 to 10 on the scale) the PP on its own.

However, upon analysis of the relationship between nationalism and political sympathy (Figure 6) we can observe how those spaces of an ideological nature are broken, producing a realignment in terms of the nationalist drive shaft. In fact, except in the case of supporters of the PP and CUP, which maintain a perfectly immutable ideological and nationalist space, supporters of the other parties are beginning to move in differential manner, revealing the tension between the nationalist and the ideological axis. This is the case of supporters of IU, PODEMOS or UDC, as occurs in more central positions with PSOE and Ciudadanos voters, very far apart in the previous exclusively ideological analysis. However, given its enormous importance within this entire process of national construction, we should highlight the case of $\mathrm{CiU}$ voters, ideologically very far from their coalition partners and who fit perfectly into this new space, where ideology ceases to be important (Figure 6).

\subsection{Factors of Mobilisation}

Jaraiz (2016) has recently shown how in 2015 nationalist leaders in Catalonia not

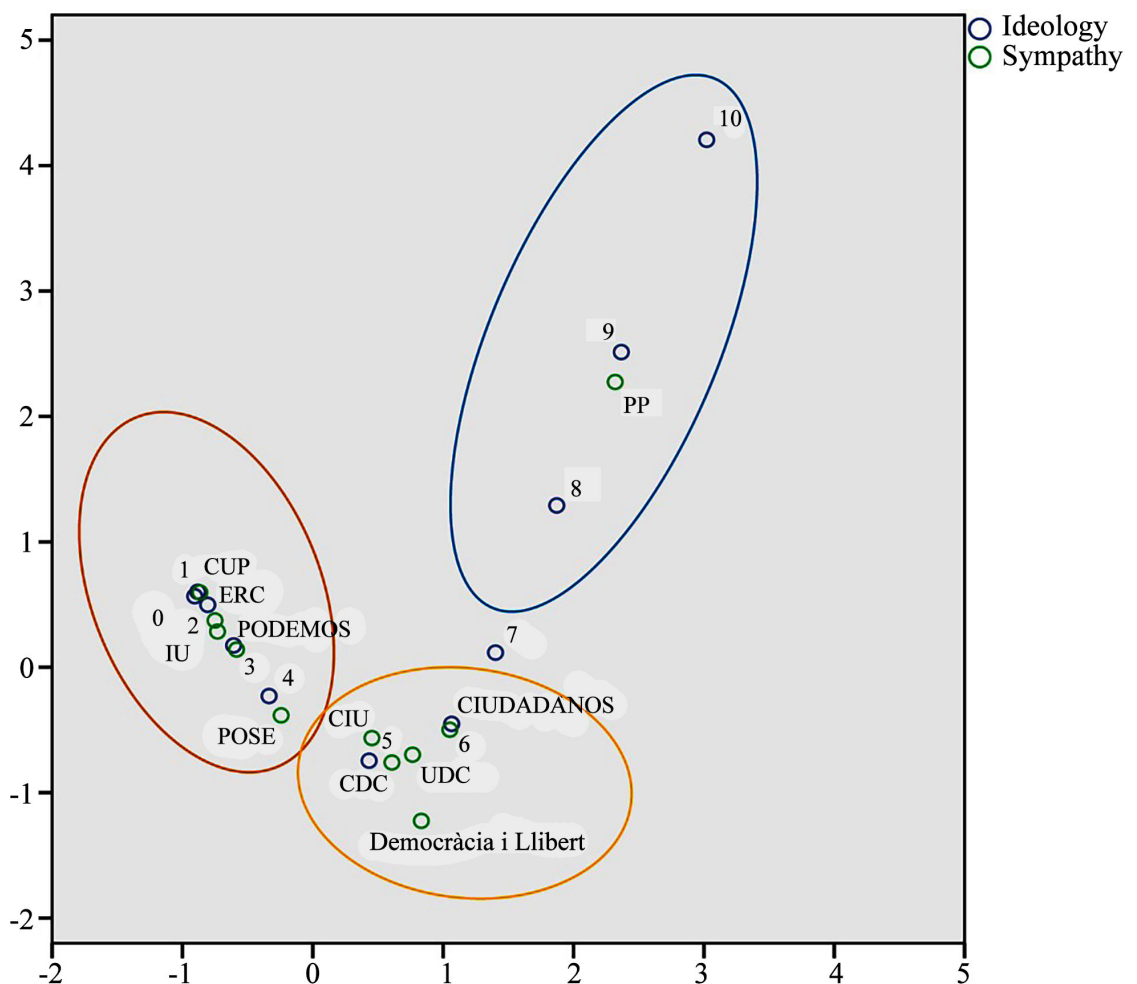

Figure 5. Analysis of the correspondences between self-placement on the ideological scale and political sympathy. Source: Own data from the Post-electoral Study Autonomous Elections in Catalonia 2015. 


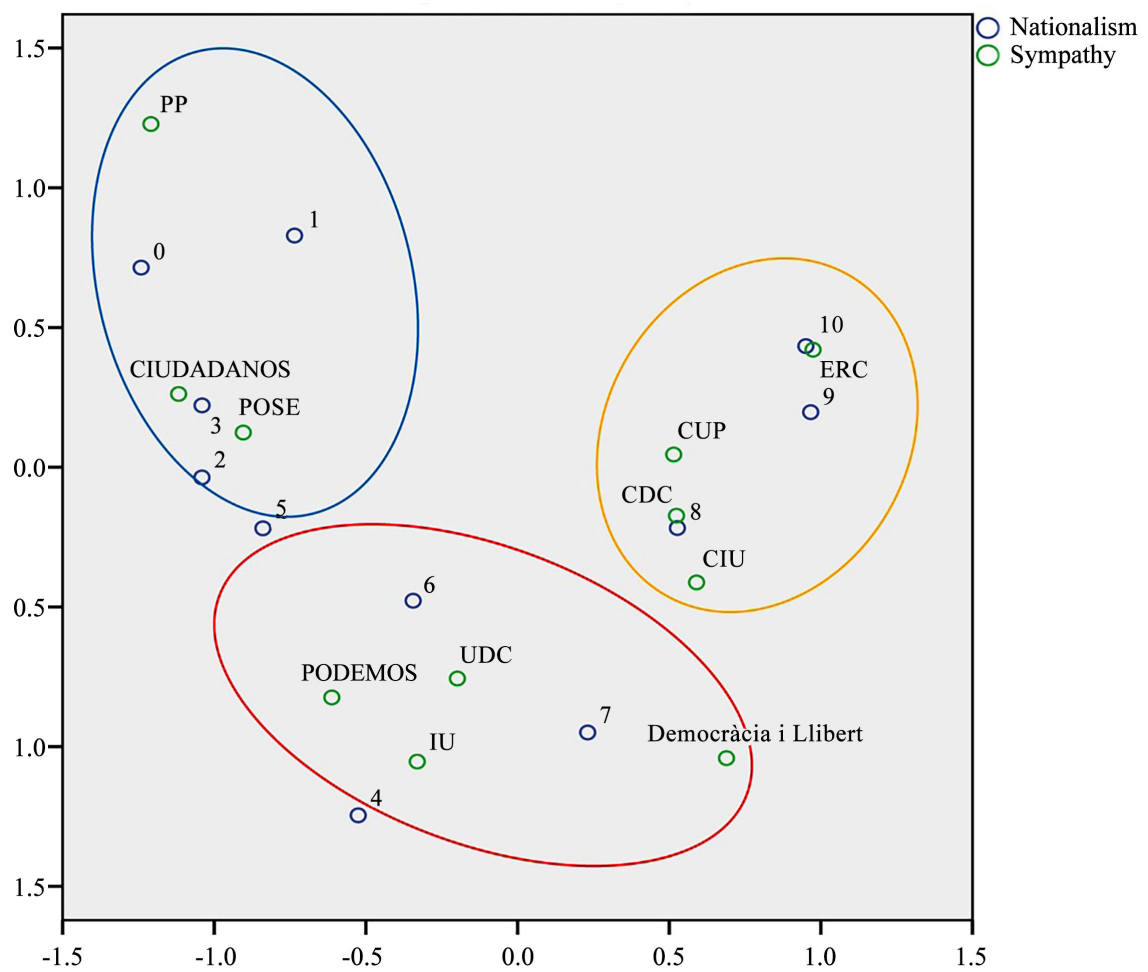

Figure 6. Analysis of correspondences between self-placement on the nationalist scale and political sympathy. Source: Own data from the Post-electoral Study Autonomous Elections in Catalonia 2015.

only built a coalition oriented towards competition, but that they occupied the whole of the nationalist space, excluding from it actors who were not sufficiently radical to embrace the process. The nationalist parties lost protagonism to cede it to a coalition-instrument and an innovative "shared leadership", presenting the electoral process as a plebiscite, for the public policies, which could have made the competition pivot on the ideological axis, to give prominence to the nationalist axis.

Three elements are fundamental in order to understand how the mobilisation has been produced: firstly the role of the process, secondly the unifying role of leaders, and finally, how long citizens have supported the independence process. Both the process and the role of leaders have been discussed in various chapters of this book and subsequently we will show their functioning in our SEM model; time, however, deserves special comment.

Table 4 shows us the relationship between the length of time during which citizens have sympathised with independence and the average positioning on the nationalist scale. What strikes us first was the average positioning of those who have supported Independence for less than a year (6.43) is very close to the average of Catalans (6.23), and secondly, the fact that those who have supported independence for five years or less occupy nationalist positions inferior to the average.

The gradual adhesion of citizens to the independentist option and the evolu- 
tion of nationalist positions is even more patent when, beyond the average of self-placements, we study the position occupied by citizens depending on time, on how long they have supported independence. Table 5 shows us the diversity of positions and makes it clear that, though there is a close relationship between ideological positioning and independentist sentiment, this relationship varies as a function of how long citizens have professed it.

Thus, the idea of supposed nationalist homogeneity also clashes with the differences associated with the strategic positions assumed under the mobilisation itself, and the issues which accompanied that mobilisation. The idea that the process becomes a producer of identity, and that the length of time during which each citizen has supported the secessionist movement (process) is fundamental in order to understand the nuances associated with the national reading of each are now evident; as evident too is the fact that this nationalist heterogeneity presented by the electoral competition in ambiguous manner contains plural readings of Catalonia as Nation, unified around the process assumed as "master frame" of a competition that does not end with the electoral process.

\subsection{The Discourse: The "Process" and the Essentialist/Strategic Dialectic}

If the process is shaped as the master frame of the construction of the new Catalan identity and as the issue of competition that generates mobilisation, the grounds for being in favour of or against the process determine the elements upon which the new identity-based construction is based. In fact the secessionist process has become the fundamental protagonist of the discourse.

When we analyse the grounds for citizens being in favour of the independence process, it is clear that the strategic grounds, "Spain treats us badly" or "the economic future of Catalonia will be better outside Spain", prevail over essentially identity-based grounds (Table 6).

Table 4. Comparison of average self-placement on the nationalist scale according to length of time supporting independence.

\begin{tabular}{cccc}
\hline & Average & N & Standard Deviation \\
\hline Always & 8.48 & 294 & 2.063 \\
Over five years & 8.63 & 43 & 1.169 \\
For five years & 7.76 & 171 & 1.614 \\
For three years & 6,75 & 56 & 2.271 \\
For a year & 6.43 & 22 & 2.366 \\
Over five years & 8.63 & 43 & 1.169 \\
DK/NA & 5.05 & 39 & 2.455 \\
Total & 7.85 & 625 & 2.171 \\
\hline
\end{tabular}

Source: Own data from the Post-electoral Study Autonomous Elections in Catalonia 2015. 
Table 5. Self-placement on the nationalist scale depending on time supporting independence.

\begin{tabular}{|c|c|c|c|c|c|c|c|c|}
\hline \multicolumn{9}{|c|}{ How long have you supported independence? } \\
\hline & & Always & $\begin{array}{l}\text { Over five } \\
\text { years }\end{array}$ & $\begin{array}{l}\text { For five } \\
\text { years }\end{array}$ & $\begin{array}{c}\text { For three } \\
\text { years }\end{array}$ & $\begin{array}{l}\text { For a } \\
\text { year }\end{array}$ & $\mathrm{DK} / \mathrm{NA}$ & Total \\
\hline & 0 & $1.40 \%$ & & & & $8.70 \%$ & $10.00 \%$ & $1.60 \%$ \\
\hline & 1 & $0.00 \%$ & & & $3.70 \%$ & & & $0.30 \%$ \\
\hline & 2 & $0.70 \%$ & & & $1.90 \%$ & & & $0.50 \%$ \\
\hline & 3 & $1.70 \%$ & & & & $4.30 \%$ & & $1.00 \%$ \\
\hline \multirow{7}{*}{$\begin{array}{l}\text { Self-placement on } \\
\text { Nationalist scale }\end{array}$} & 4 & $2.40 \%$ & $0.00 \%$ & $3.50 \%$ & $11.10 \%$ & & $17.50 \%$ & $4.20 \%$ \\
\hline & 5 & $3.10 \%$ & $2.30 \%$ & $7.60 \%$ & $7.40 \%$ & $4.30 \%$ & $47.50 \%$ & $7.50 \%$ \\
\hline & 6 & $3.10 \%$ & & $7.60 \%$ & $20.40 \%$ & $17.40 \%$ & $2.50 \%$ & $6.10 \%$ \\
\hline & 7 & $8.50 \%$ & $11.60 \%$ & $22.70 \%$ & $18.50 \%$ & $26.10 \%$ & $2.50 \%$ & $13.80 \%$ \\
\hline & 8 & $1,10 \%$ & $32.60 \%$ & $27.30 \%$ & $16.70 \%$ & $34.80 \%$ & $10.00 \%$ & $21.10 \%$ \\
\hline & 9 & $17.10 \%$ & $25.60 \%$ & $12.20 \%$ & $5.60 \%$ & $4.30 \%$ & $2.50 \%$ & $13.90 \%$ \\
\hline & 10 & $45.10 \%$ & $27.90 \%$ & $19.20 \%$ & $14.80 \%$ & & $7.50 \%$ & $30.10 \%$ \\
\hline
\end{tabular}

Source: Own data from the Post-electoral Study Autonomous Elections in Catalonia 2015.

Table 6. Main grounds in support of the independence process in Catalonia.

\begin{tabular}{cc}
\hline $\begin{array}{c}\text { Because I believe that Catalonia has not been treated fairly by the Government of } \\
\text { Spain in recent years }\end{array}$ & 65.5 \\
\hline $\begin{array}{c}\text { Because I believe that the economic future of Catalonia and of Catalan society will be } \\
\text { better outside Spain }\end{array}$ & 30.6 \\
Because I understand that Catalonia is a nation & 30.0 \\
Because there are historical grounds that justify it & 21.1 \\
Because I do not feel Spanish & 16.0 \\
Others. Which? & 5.1 \\
DK/NA & 0.6
\end{tabular}

Source: Own data from the Post-electoral Study Autonomous Elections in Catalonia 2015.

The data from our study reveals the existence of a hegemonic framework, "the process", via which narratives are articulated, both those of a structural and of an essentialist nature, which become issues of competition and sustain the very construction of identity. Traditional elements of identity-based construction lose influence, which is gained by strategic grounds articulated around the process. But the fact that the discourse is constructed around economic and political factors, rather than on the basis of essentialist ones (Language, culture, history etc.) does not make national construction weaker, as might be thought from an ethnicist or structural perspective, to the contrary, as we have seen, it is capable of generating realignments that transcend the sociological and ideological differences. Our explanatory model seeks to incorporate these political elements to 
analyse the weight of each of them in the construction of the national identity of Catalonia today.

\section{The Components of the Explanation of Catalan Nationalism}

In order to construct a model that explains the components in the study of nationalism, we have grouped and recoded information with regard to the main determining factors which from a theoretical point of view enable allow for an explanation of nationalism in Catalonia. In this respect, we opted for the application of structural equation models (SEM), insofar as the nature of information and analytical capacity of this technique made this advisable. To this end, the first step consisted in an exploratory factor analysis with which to determine the sets of really significant variables in the final construction of the model, and the corresponding univariate normality test. The final result led to the creation of a series of analytical constructs which correspond to various explanatory levels in the final model. This, in that it articulates and interrelates different dimensions, enables us to prepare a multidimensional response to the object of our research. In this sense, the final solution presents a series of latent constructs, and intervening variables that correspond to a space of symmetry between pro-Catalan and pro-centralist attitudes (the left and right spaces of the equation), in the same way that it interrelates attitudinal dimensions, and of leadership in the higher, medium and lower levels, respectively.

The endogenous variable is self-placement on the nationalist scale (NATIONALISM) and upon this we have analyzed a series of variables corresponding to the following latent constructs (Table 7):

1) Firstly we find contextual elements of a political and economic nature, which act as preconditions, sustaining sentiments of confidence or rejection towards Catalonia or the rest of the Country.

ConfidenceCAT: Confidence in the Catalan political class and in the ability of Catalan politicians to represent the interests of Catalonia.

ConfidenceESP: Confidence in the Spanish political class and in the ability of Spanish politicians to represent the interests of Catalonia.

EvolutionCAT: Prospective assessments of the political and economic evolution of Catalonia in the future after becoming an independent State.

2) Secondly a construct related to leadership, as a generator of mobilisation, which acts in Catalonia and in the rest of Spain.

LeadershipCAT: Includes the ratings of Artur Mas, Raúl Romeva and Oriol Junqueras.

LeadershipESP: Includes the ratings of Mariano Rajoy, Pedro Sánchez and Albert Rivera (the most significant Spanish politicians as neither Pablo Iglesias nor Alberto Garzón contributed significantly to the model).

3) Lastly, a series of mediating variables, which represent the intermediate level in the equation and would be formed by classical elements in the configuration of nationalism and which in our scheme appear as preconditions 
(LANGUAGE) as factors of mobilisation (TIME), elements of discourse and issues that generate the structure of opportunity (PROCESS).

Before beginning with the display of the results produced by the application of our model we will present the global adjustment measures of the latter, with the aim of establishing the parameters of suitability of the model, be they the RMSEA $^{7}$ value, or the incremental adjustment measures of the model, NFI and $\mathrm{CFI}^{8}$, the most usual in adjusting structural equations models.

Table 7. Codification of the variables present in the SEM model.

\begin{tabular}{|c|c|c|}
\hline VARIABLE & TYPE & CATEGORIES \\
\hline NATIONALISM & Scale & $0-10$ \\
\hline$C O N F_{-} C A T$ & Scale & $0-10$ \\
\hline$C O N F_{-} E S P$ & Scale & $0-10$ \\
\hline$P O L I \_R E P R E \_C A T$ & Scale & $0-10$ \\
\hline$P O L I \_R E P R E \_E S P$ & Scale & $0-10$ \\
\hline$E V \_E C O N O M Y$ & Ordinal & will improve, will remain the same, will deteriorate \\
\hline$E V \_P O L I T I C S$ & Ordinal & will improve, will remain the same, will deteriorate \\
\hline$L A N G U A G E$ & Scale & $\begin{array}{c}\text { Catalan, Spanish, indifferent, more in Catalan than in } \\
\text { Spanish, more in Spanish than in Catalan. }\end{array}$ \\
\hline$T I M E$ & Scale & in favour, against \\
\hline PROCESS & Dichotomous & in favour, against \\
\hline$M A S$ & Scale & $0-10$ \\
\hline JUNQUERAS & Scale & $0-10$ \\
\hline$R O M E V A$ & Scale & $0-10$ \\
\hline$R A J O Y$ & Scale & $0-10$ \\
\hline$S A N C H E Z$ & Scale & $0-10$ \\
\hline$R I V E R A$ & Scale & $0-10$ \\
\hline
\end{tabular}

Source: Own data from the Post-electoral Study Autonomous Elections in Catalonia 2015.

${ }^{7}$ The most robust goodness-of-fit index proposed is the Root Mean Squared Error Approximation (RMSEA). This index has been developed as an absolute measure of the difference in the structure of relations between the model proposed and the covariance values in population measured. The term comes from the initial measure of difference between the data and the model. The importance of this index lies in the fact that it reflects an absolute difference between the model proposed and the data observed, taking into account the number of estimations and the size of the sample involved for the model on trial (Steiger, 1990). It is very important to note that this index, due to its origin and statistical properties, compares the model with the structure of relation between the variables in the population. The interpretation of the indicator is as follows:

- When the RMSEA presents values below 0.10 there is an indication of good fit between the measurement model and the structure of the data.

- When the RMSEA values are below 0.05 the fit between the model and the data is considered to be superior.

- When the RMSEA values are below 0.01 the fit between the model and the data is outstanding.

${ }^{8}$ The Goodness of Fit Index (GFI), is an index of variability which is explained by the model, its values oscillating between 0 (poor fit) and 1 (perfect fit). Values higher than 0.90 are accepted as indicative of an acceptable fit of the model. 
The results of this test demonstrate that this is a correctly adjusted SEM model, always within the values determined as appropriate in each of the three values (Table 8).

The results of our model (Figure 7) show that the explanation of nationalism in Catalonia arises as derivation of different constructs, with different components, which encompass factors referring to preconditions, structure of opportunity, discourse and elements of mobilisation, especially leadership, primordial when it comes to understanding the position of the Catalans on the nationalist scale, insofar as it has acted as a strengthening element of the recent reconstruction of identity-based sentiment.

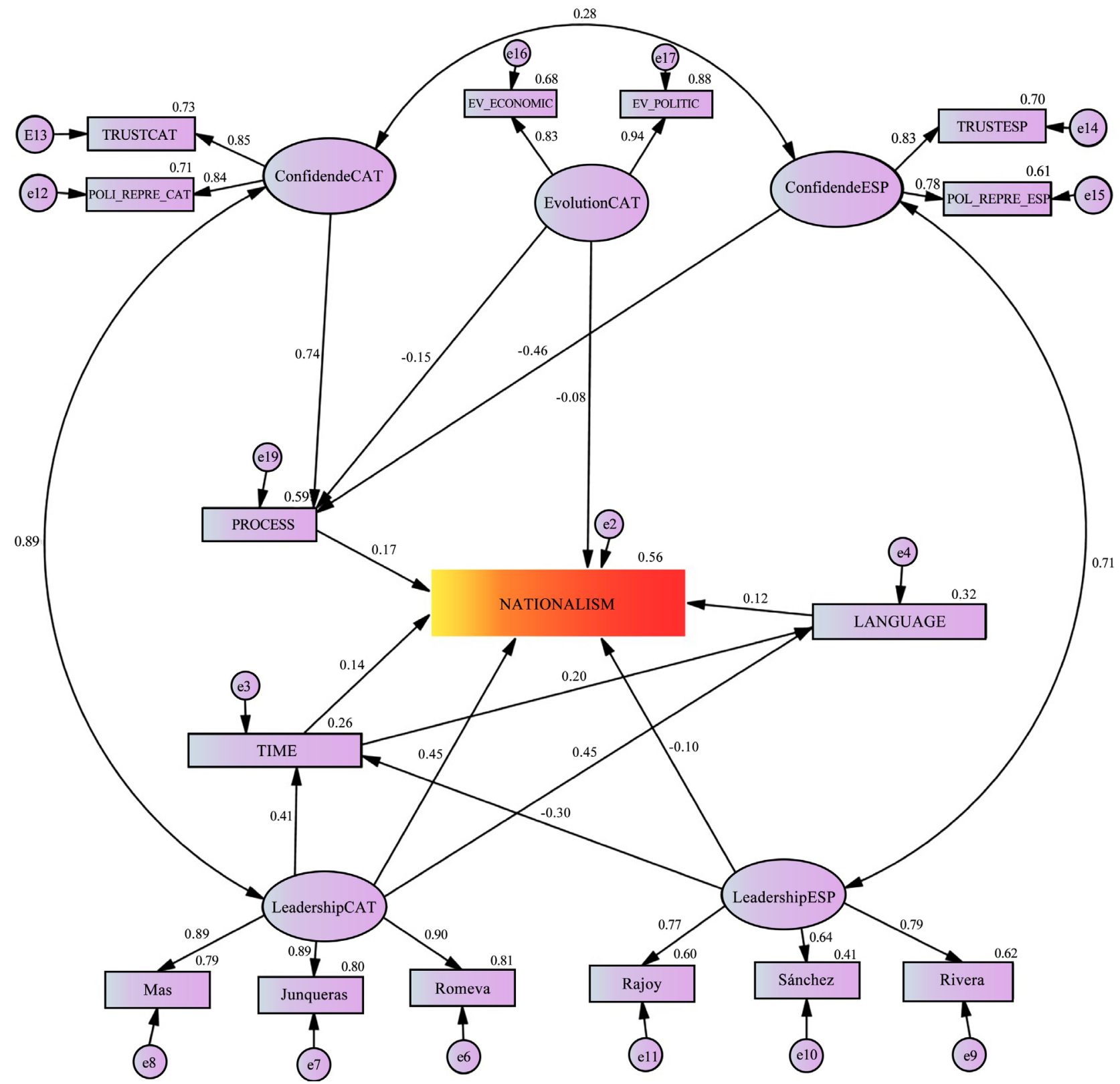

Figure 7. SEM model. Components of the new Catalan nationalism. Source: Own data Post-electoral Study Autonomous Elections in Catalonia 2015. 
Table 8. Model's adjustment measures.

\begin{tabular}{cccc}
\hline & NFI & CFI & RMSEA \\
\hline Model Catalan nationalism & 0.910 & 0.901 & 0.069 \\
\hline
\end{tabular}

Source: Own data from the Post-electoral Study Autonomous Elections in Catalonia 2015.

In this respect, it shows the considerable influence that leaderships, both Catalan and Spanish, exercise. Specifically, on the part of Catalonia, we observe that leadership impacts directly and indirectly upon the articulation of nationalist sentiment, directly in that the evaluation of the leadership of the three "Catalanist" politicians, Artur Mas, Oriol Junqueras y Raül Romeva, largely explains the variability on the nationalist scale (45 per cent), in the same way that, on the non-nationalist side, Mariano Rajoy, Pablo Iglesias and Albert Rivera explain, inversely, the 10 per cent variability in the data on this Scale. Within the latent constructs referring to LeadershipCAT the three leaders have similar weight (close to 90 per cent), while on the side of LeadershipESP, the leaders with most weight in the construct are Albert Rivera (79\% per cent) Mariano Rajoy (77 per cent) and Pedro Sánchez (64 per cent).

Similarly, the relationship between nationalism and leadership is also produced indirectly, insofar as leadership sustains visions of the political and economic context at both levels, Spanish and Catalan. Specifically, Catalan leadership explains 89 per cent of perceptions with regard to the political and economic context in Catalonia (ConfidenceCAT), meanwhile Spanish leadership explains 71 per cent of the economic and political context of Spain (ConfidenceESP).

On this same level of preconditions we observe how expectations regarding the evolution of the economy and politics in Catalonia have a significant effect upon nationalism, in fact there is 8 per cent of variability on the scale, so optimism in relation to the evolution of the political and economic context results in higher self-placement on the nationalist scale.

With regard to one of the central cultural elements, language, we observe that the valuation of Catalan leadership explains 45 per cent of the variability of this variable, suggesting that the greater the valuation of leadership, the higher the probability of expressing oneself only in Catalan. Language, in turn, has only a moderate influence upon nationalist self-placement (12 per cent), let us not forget, this was traditionally one of the fundamental axes in the justification of nationalism. Things have changed, these days are the leadership variable which impacts upon language, and through the latter has indirect effects upon identity. All this also indicates the comparative loss of weight of traditional elements of explanation of the Catalan nationalism.

In similar fashion, the other main axis about which the mechanism of nationalist reconstruction has revolved has been the secessionist mobilization itself, "the process", with our analysis showing how the effects on the nationalism variable are important, both via the time variable, in other words, the moment 
when people subscribed to secessionist sentiment, and their option regarding the same process. Specifically, the process explains 17 per cent of the variability of the scale, that is, more nationalism among those who are in favour of the independentist process (Table 9).

Table 9. Effects, totals, direct and indirect (standardised).

\begin{tabular}{|c|c|c|c|c|c|c|c|c|}
\hline \multicolumn{9}{|c|}{ Standardised total effects } \\
\hline & $\begin{array}{c}\text { Confidence } \\
\text { ESP }\end{array}$ & $\begin{array}{c}\text { Confidence } \\
\text { CAT }\end{array}$ & $\begin{array}{l}\text { Leadership } \\
\text { ESP }\end{array}$ & $\begin{array}{c}\text { Leadership } \\
\text { CAT }\end{array}$ & $\begin{array}{c}\text { Evolution } \\
\text { CAT }\end{array}$ & TIME & PROCESS & LANGUAGE \\
\hline TIME & 0 & 0 & -0.305 & 0.408 & 0 & 0 & 0 & 0 \\
\hline PROCESS & -0.459 & 0.739 & 0 & 0 & -0.149 & 0 & 0 & 0 \\
\hline LANGUAGE & 0 & 0 & -0.062 & 0.536 & 0 & 0.203 & 0 & 0 \\
\hline EV_POLITICS & 0 & 0 & 0 & 0 & 0.936 & 0 & 0 & 0 \\
\hline EV_ECONOMY & 0 & 0 & 0 & 0 & 0.825 & 0 & 0 & 0 \\
\hline POL_REPRE_ESP & 0.778 & 0 & 0 & 0 & 0 & 0 & 0 & 0 \\
\hline TRUSTESP & 0.835 & 0 & 0 & 0 & 0 & 0 & 0 & 0 \\
\hline TRUSTCAT & 0 & 0.853 & 0 & 0 & 0 & 0 & 0 & 0 \\
\hline POLI_REPRE_CAT & 0 & 0.842 & 0 & 0 & 0 & 0 & 0 & 0 \\
\hline MARIANO RAJOY & 0 & 0 & 0.774 & 0 & 0 & 0 & 0 & 0 \\
\hline PEDRO SÁNCHEZ & 0 & 0 & 0.643 & 0 & 0 & 0 & 0 & 0 \\
\hline RIVERA & 0 & 0 & 0.79 & 0 & 0 & 0 & 0 & 0 \\
\hline MAS & 0 & 0 & 0 & 0.887 & 0 & 0 & 0 & 0 \\
\hline JUNQUERAS & 0 & 0 & 0 & 0.893 & 0 & 0 & 0 & 0 \\
\hline ROMEVA & 0 & 0 & 0 & 0,9 & 0 & 0 & 0 & 0 \\
\hline NATIONALISM & -0.076 & 0.123 & -0.149 & 0.573 & -0.107 & 0.165 & 0.166 & 0.117 \\
\hline \multicolumn{9}{|c|}{ Standardised direct effects } \\
\hline & $\begin{array}{c}\text { Confidence } \\
\text { ESP }\end{array}$ & $\begin{array}{c}\text { Confidence } \\
\text { CAT }\end{array}$ & $\begin{array}{l}\text { Leadership } \\
\text { ESP }\end{array}$ & $\begin{array}{c}\text { Leadership } \\
\text { CAT }\end{array}$ & $\begin{array}{c}\text { Evolution } \\
\text { CAT }\end{array}$ & TIME & PROCESS & LANGUAGE \\
\hline TIME & 0 & 0 & -0.305 & 0.408 & 0 & 0 & 0 & 0 \\
\hline PROCESS & -0.459 & 0.739 & 0 & 0 & -0.149 & 0 & 0 & 0 \\
\hline LANGUAGE & 0 & 0 & 0 & 0.453 & 0 & 0.203 & 0 & 0 \\
\hline EV_POLITICS & 0 & 0 & 0 & 0 & 0,936 & 0 & 0 & 0 \\
\hline EV_ECONOMY & 0 & 0 & 0 & 0 & 0.825 & 0 & 0 & 0 \\
\hline POL_REPRE_ESP & 0.778 & 0 & 0 & 0 & 0 & 0 & 0 & 0 \\
\hline TRUSTESP & 0.835 & 0 & 0 & 0 & 0 & 0 & 0 & 0 \\
\hline TRUSTCAT & 0 & 0.853 & 0 & 0 & 0 & 0 & 0 & 0 \\
\hline POLI_REPRE_CAT & 0 & 0.842 & 0 & 0 & 0 & 0 & 0 & 0 \\
\hline RAJOY & 0 & 0 & 0.774 & 0 & 0 & 0 & 0 & 0 \\
\hline SÁNCHEZ & 0 & 0 & 0.643 & 0 & 0 & 0 & 0 & 0 \\
\hline
\end{tabular}




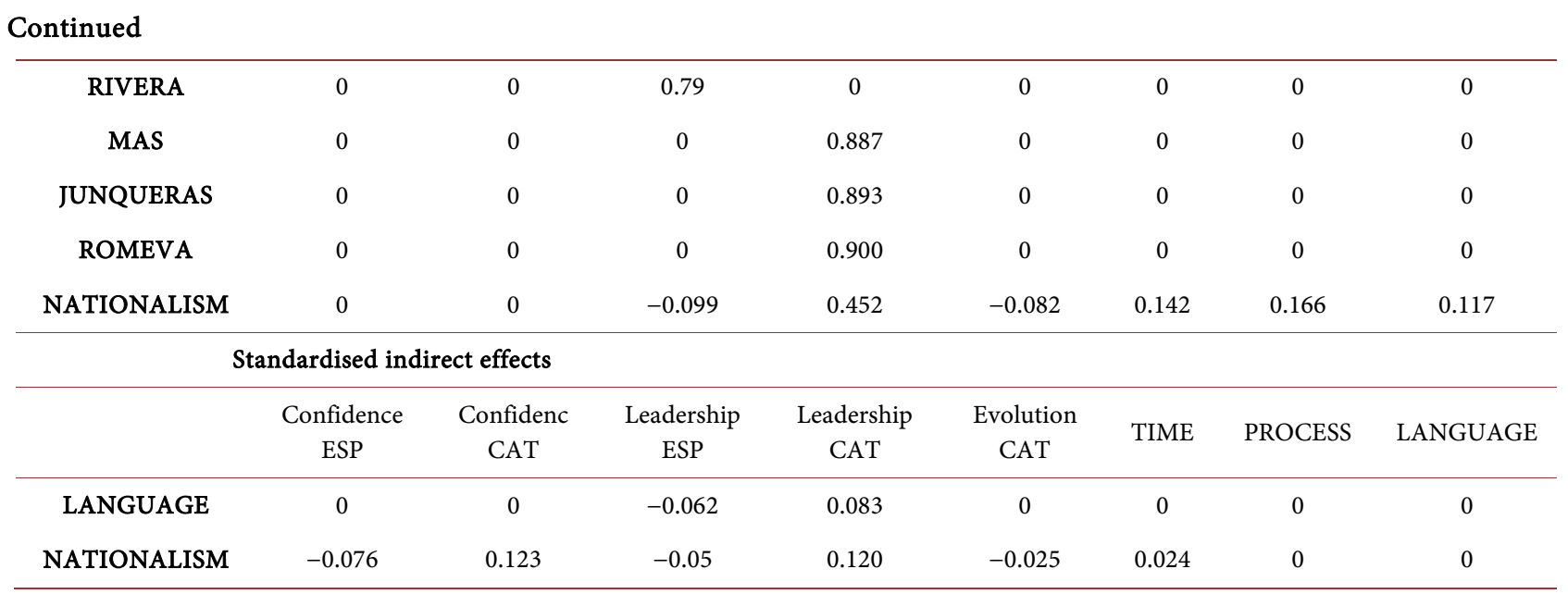

Source: Own data Post-electoral Study Autonomous Elections in Catalonia 2015.

Similarly, the process itself receives a series of direct and indirect effects, again related to the latent constructs of confidence in Catalonia and Spain. The ConfidenceCAT construct explains 74 per cent of the support for the Independence process, in the sense that the greater the confidence in Catalan politics and defence of Catalan interests by politicians, the greater the support for the process, whilst in the case of ConfidenceESP this occurs in the inverse sense $(-46$ per cent), so the greater the confidence in Spanish politics and politicians, the greater the opposition to the process.

Finally, an important element is the moment when citizens assumed this secessionist stance, influencing the idea of construction of nationalist sentiments, and above all, analysing the role of leadership in this process of development and consolidation of the latter. In this respect, the relationship between Catalan leadership and the moment of embracing these secessionist sentiments is very strong (0.41) explaining how greater strength in valuations of leadership in Catalonia correlate with higher temporal proximity in the incorporation of these nationalist and secessionist tenets. This data supports the idea about the strategic role of leadership in the reconstruction of nationalist sentiments, specifying not only the relationship between them, but also the indirect impact upon support for the process, in such a way that it acts as an important element that reinforces attitudes in favour of the latter. In other words, the more positive valuations of leadership affect the moment, closer in time, incorporating values and attitudes that, in turn, represent support for the process itself and reinforcement of nationalism.

\section{Conclusion}

Throughout this article we identify four fundamental factors in the construction of the Catalan nation: social and ethnic preconditions, structure of opportunity, mobilisation and discourse. These four factors integrate a series of components which act as indicators in the construction of our Structural Equations Model. 
This allows us to introduce a new explanation of nationalism in Catalonia, which arises as derivation of different constructs, encompassing the mentioned four factors.

On the one hand, we focus on contextual elements of a political and economic nature, which act as preconditions. We show how expectations regarding the evolution of the economy and politics in Catalonia have a significant effect upon nationalism, so optimism in relation to the evolution of the political and economic context results in higher self-placement on the nationalist scale. Language, in turn, has only a moderate influence upon nationalist self-placement, which indicates the comparative loss of weight of the traditional elements of explanation of the Catalan nationalism.

By the other hand we found that there are some elements of mobilisation, especially leadership, which are primordial when it comes to understand the position of the Catalans on the nationalist scale, insofar as it has acted as a strengthening element of the recent reconstruction of identity-based sentiment. Leadership impacts directly and indirectly upon the articulation of nationalist sentiment. Directly in that the good evaluation of the leadership of both "Catalanist" politicians and those on the non-nationalist side, has a positive and negative effect, respectively, on the nationalist sentiment. This also contributes to explain the strategy of the Catalan political actors, who have bypassed the ideological axis of the competition to focus exclusively on the nationalist one. Moreover, the relationship between nationalism and leadership is also produced indirectly, insofar as leadership sustains visions of the political and economic context at both levels, Spanish and Catalan.

Finally, a third factor of explanation of Catalan nationalism has been the secessionist mobilization itself, "the process", with our analysis showing how the effects of it on the nationalism variable are important, both via the time variable and their option regarding the same process. Thus it makes sense that electoral realignments and the evolution of positions in the order of identity, or even of the preferences for independence, do not necessarily have to be homogenous, but can lead to different options with regard to the question of territorial solution, amongst others. If something has been made clear throughout these pages, it is that the Catalonia national identity has essentialist and strategic components, and that there are fundamental differences between traditional and new nationalists, as while the former have constructed their identity on the basis of the idea of a pre-existing nation, the latter have built the nation for reasons that have to do with unjust treatment by Spanish governments, trust and expectations. And this is the fundamental conclusion of the present paper.

This new idea of nation does not make it weaker or more volatile. On the contrary, generates a shared decision of nation that is more conscious, more deliberate, more activated and consistent in that its assumption forms part of the very act of national political construction. The actual elements of the construction render it less teleological than the idea of a historical nation pre-existing in time in its quest for independence. Indeed, whilst the logic of demand, im- 
printed on the traditional nationalist world of Catalonia, demands Independence via a nation that pre-exists political action, the logic of offer, which gives way to the built nation, finds in heterogeneity and plurality, as the model shows, not only the mobilising resources of its own construction but, also, the alternative exits from the conflict itself.

This work shows that the components of nationalism are not static. In the face of the idea that the nation builds the nationalism, is the nationalist mobilization which builds the nation, and therefore, the issues that feed the mobilization become dynamic components of national construction.

This reading extends the boundaries of the understanding of national phenomena, and requires new analyses that, in our case, are oriented toward the study of the influence of the emotions in national construction.

\section{Conflicts of Interest}

The authors declare no conflicts of interest regarding the publication of this paper.

\section{References}

Anderson, B. (1983). Imagined Communities. London: Verso.

Boonen, J., \& Hooghe, M. (2014). Do Nationalist Parties Shape or Follow Sub-National Identities? A Panel Analysis on the Rise of the Nationalist Party in the Flemish Region of Belgium, 2006-2011. Nations and Nationalism, 20, 56-79.

https://doi.org/10.1111/nana.12044

Brubaker, R. (1996). Nationalism Reframed. Cambridge: Cambridge University Press. https://doi.org/10.1017/CBO9780511558764

Hale, H. E. (2008). The Foundations of Ethnic Politics. New York: Cambridge University Press. https://doi.org/10.1017/CBO9780511790669

Hobsbawm, E. (1998). Naciones y Nationalismo desde 1780. Barcelona: Hurope.

Hobsbawm, E. J., \& Ranger, T. O. (1983). The Invention of Tradition. Cambridge: CUP.

Jaraiz, E. (2016). Los líderes como facilitadores del posicionamiento de los electores. In J. M. Rivera, J. Montabes, \& N. Lagares (Eds.), Cataluña en proceso. Las elecciones autonómicas de 2015 (pp. 127-148). Valencia: Tirant Lo Blanch.

Keating, M. (2009). The Independence of Scotland. Oxford: Oxford University Press. https://doi.org/10.1093/acprof:oso/9780199545957.001.0001

Keating, M. (2012). Rethinking Sovereignty. Independence-Lite, Devolution-Max and national Accommodation. Revista d'Estudis Autonomics y federals, 16, 9-29.

Kumar, K. (2006). The Sage Handbook of Nations and Nationalism. Thousand Oaks: Sage.

Kymlicka, W. (2001). Politics in the Vernacular. Oxford: Oxford University Press. https://doi.org/10.1093/0199240981.001.0001

Laitin, D. (2007). Nations, States and Violence. New York: Oxford University Press. https://doi.org/10.1093/acprof:oso/9780199228232.001.0001

Máiz, R. (2003a). Politics and the Nation: Nationalist Mobilization of Ethnic Differences. Nations and Nationalism, 9, 195-214. https://doi.org/10.1111/1469-8219.00082

Máiz, R. (2003b) Framing the Nation: Three Rival Versions of Contemporary Nationalist 
Ideology. Journal of Political Ideologies, 8, 251-270.

https://doi.org/10.1080/1356931032000131165

Máiz, R. (2012). The Inner Frontier. Brussels: Peter Lang. https://doi.org/10.3726/978-3-0352-6130-1

Pereira, M. (2016). Lectura espacial de la competición política. In Rivera, Montabes, \& Lagares (Eds.), Cataluña en proceso. Las elecciones autonómicas de 2015 (pp. 106-125). Valencia: Tirant Lo Blanch.

Prat, S. (2012). El suport a la independència de Catalunya. Anàlisi de canvis i tendències en el període 2005-2012. Barcelona: CEO.

Rezvani, D. A. (2014). Surpassing the Sovereign State. New York: Oxford University Press. https://doi.org/10.1093/acprof:oso/9780199688494.001.0001

Rico, G., \& Jennings, M. K. (2012). The Intergenerational Transmission of Contending Place Identities. Political Psychology, 33, 723-742. https://doi.org/10.1111/j.1467-9221.2012.00894.x

Rivera, J. M., \& Jaráiz, E. (2016). Modelos de explicación y componentes del voto en las elecciones autonómicas catalanas de 2015. Revista Española de Ciencia Política, 42, 13-43. https://doi.org/10.21308/recp.42.01

Shelef, N. (2010). Evolving Nationalism. Ithaca, NY: Cornell University Press.

\section{Appendix}

- CiU: Convergéncia i Unió.

- CDC: Convergéncia Democrática de Catalunya.

- ERC: Esquerra Republicana de Catalunya.

- JxSí: Junts pel Sí.

- PSC: Partit dels Socialistes de Catalunya.

- C's: Ciutadans.

- CQESP: CatSíQueEsPot o Catalunya Sí que es Pot.

- PP: Partido Popular.

- CUP: Candidatura d'Unitat Popular. 